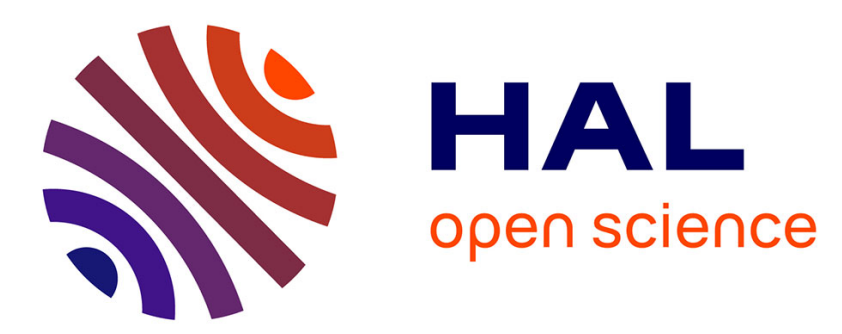

\title{
A late medieval warm period in the Southern Ocean as a delayed response to external forcing?
}

H. Goosse, V. Masson-Delmotte, H. Renssen, M. Delmotte, T. Fichefet, V. Morgan, T. van Ommen, B. Khim, B. Stenni

\section{- To cite this version:}

H. Goosse, V. Masson-Delmotte, H. Renssen, M. Delmotte, T. Fichefet, et al.. A late medieval warm period in the Southern Ocean as a delayed response to external forcing?. Geophysical Research Letters, 2004, 31 (6), pp.L06203. 10.1029/2003GL019140 . hal-03103293

\section{HAL Id: hal-03103293 \\ https://hal.science/hal-03103293}

Submitted on 11 Jan 2021

HAL is a multi-disciplinary open access archive for the deposit and dissemination of scientific research documents, whether they are published or not. The documents may come from teaching and research institutions in France or abroad, or from public or private research centers.
L'archive ouverte pluridisciplinaire HAL, est destinée au dépôt et à la diffusion de documents scientifiques de niveau recherche, publiés ou non, émanant des établissements d'enseignement et de recherche français ou étrangers, des laboratoires publics ou privés. 


\title{
VU Research Portal
}

\section{A late medieval warm period in the Southern Ocean as a delayed response to external forcing?}

Goosse, H.; Masson-Delmotte, V.; Renssen, H.; Delmotte, M.; Fichefet, T.; Morgan, V.; van Ommen, T.; Khim, B.K.; Stenni, B.

\author{
published in \\ Geophysical Research Letters \\ 2004
}

\section{DOI (link to publisher) \\ 10.1029/2003GL019140}

\section{document version}

Publisher's PDF, also known as Version of record

\section{Link to publication in VU Research Portal}

\section{citation for published version (APA)}

Goosse, H., Masson-Delmotte, V., Renssen, H., Delmotte, M., Fichefet, T., Morgan, V., van Ommen, T., Khim, B. K., \& Stenni, B. (2004). A late medieval warm period in the Southern Ocean as a delayed response to external forcing? Geophysical Research Letters, 31. https://doi.org/10.1029/2003GL019140

\section{General rights}

Copyright and moral rights for the publications made accessible in the public portal are retained by the authors and/or other copyright owners and it is a condition of accessing publications that users recognise and abide by the legal requirements associated with these rights.

- Users may download and print one copy of any publication from the public portal for the purpose of private study or research.

- You may not further distribute the material or use it for any profit-making activity or commercial gain

- You may freely distribute the URL identifying the publication in the public portal ?

Take down policy

If you believe that this document breaches copyright please contact us providing details, and we will remove access to the work immediately and investigate your claim.

E-mail address:

vuresearchportal.ub@vu.nl 


\title{
A late medieval warm period in the Southern Ocean as a delayed response to external forcing?
}

\author{
H. Goosse, ${ }^{1}$ V. Masson-Delmotte, ${ }^{2}$ H. Renssen, ${ }^{3}$ M. Delmotte, ${ }^{2}$ T. Fichefet, ${ }^{1}$ V. Morgan, ${ }^{4}$ \\ T. van Ommen, ${ }^{4}$ B. K. Khim, ${ }^{5}$ and B. Stenni ${ }^{6}$ \\ Received 24 November 2003; accepted 19 February 2004; published 17 March 2004.
}

[1] On the basis of long simulations performed with a three-dimensional climate model, we propose an interhemispheric climate lag mechanism, involving the long-term memory of deepwater masses. Warm anomalies, formed in the North Atlantic when warm conditions prevail at surface, are transported by the deep ocean circulation towards the Southern Ocean. There, the heat is released because of large scale upwelling, maintaining warm conditions and inducing a lagged response of about 150 years compared to the Northern Hemisphere. Model results and observations covering the first half of the second millenium suggest a delay between the temperature evolution in the Northern Hemisphere and in the Southern Ocean. The mechanism described here provides a reasonable hypothesis to explain such an interhemipsheric lag. INDEX TERMS: 1620 Global Change: Climate dynamics (3309); 4207 Oceanography: General: Arctic and Antarctic oceanography; 4532 Oceanography: Physical: General circulation; 3339 Meteorology and Atmospheric Dynamics: Ocean/atmosphere interactions (0312, 4504); 4215 Oceanography: General: Climate and interannual variability (3309). Citation: Goosse, H., V. Masson-Delmotte, H. Renssen, M. Delmotte, T. Fichefet, V. Morgan, T. van Ommen, B. K. Khim, and B. Stenni (2004), A late medieval warm period in the Southern Ocean as a delayed response to external forcing?, Geophys. Res. Lett., 31, L06203, doi:10.1029/2003GL019140.

\section{Introduction}

[2] The potential asymmetry of the climate evolution between the Northern and the Southern Hemisphere has been widely analyzed both for past and future variations. Our goal here is to further study the mechanisms that could be responsible for such a different behavior between the two hemispheres on centennial times-scales. First, we use idealized simulations performed with the climate model ECBILT-CLIO to investigate the processes behind interhemispheric relationships. In a second step, we test if the

\footnotetext{
${ }^{1}$ Institut d'Astronomie et de Géophysique G. Lemaître, UniversitéCatholique de Louvain, Louvain-la-Neuve, Belgium.

${ }^{2}$ Laboratoire des Sciences du Climat et de l'Environnement, IPSL, UMR CEA-CNRS, L'Orme des Merisiers, Gif-sur-Yvette, France.

${ }^{3}$ Faculty of Earth and Life Sciences, Vrije Universiteit Amsterdam, The Netherlands.

${ }^{4}$ Department of the Environment and Heritage, Australian Antarctic Division, and Antarctic Climate and Ecosystems CRC, Hobart, Tasmania, Australia.

${ }^{5}$ Dept. of Marine Science, Pusan National University, Pusan, Korea.

${ }^{6}$ University of Trieste, Dipartimento di Scienze Geologiche, Ambientali e Marine, Trieste, Italy.
}

Copyright 2004 by the American Geophysical Union. 0094-8276/04/2003GL019140\$05.00 mechanisms described in this simulation could explain the past evolution of temperature. The attention is focussed on the first half of the second millenium AD. Indeed, Northern Hemisphere surface temperature reconstructions consistently display relatively warm century-scale conditions at the beginning of the last millennium (the so-called "Medieval Warm Period"), although the amplitude, timing and extent of this warm event is still under debate [e.g., Mann et al., 1999; Crowley, 2000; Crowley and Lowery, 2000; Bradley, 2000]. In the present study, we check if this warm period is present in the Southern Hemisphere in the model simulations and in observations and, if it is the case, how it is related to Northern Hemisphere climate.

\section{Methods}

[3] The atmospheric component of our coupled model is ECBILT2 [Opsteegh et al., 1998], a T21, 3-level quasigeostrophic model, with simple parameterizations for the diabatic heating due to radiative fluxes, the release of latent heat and the exchange of sensible heat with the surface. ECBILT2 is coupled to the CLIO [Goosse and Fichefet, 1999] model that is made up of a primitive equation, free surface ocean general circulation model coupled to a comprehensive thermodynamic-dynamic sea ice model. The horizontal resolution of CLIO is 3 degrees in latitude and longitude, and there are 20 unevenly spaced vertical levels in the ocean. More information about the model and a complete list of references is available at http:// www.knmi.nl/onderzk/CKO/ecbilt-papers.html.

[4] As a first modelling step, a 5000-year simulation has been performed with ECBILT-CLIO using solar irradiance following an idealized sinusoidal evolution with an amplitude of $3 \mathrm{~W} \mathrm{~m} \mathrm{~m}^{-2}$ and a period of 1000 years. Taking into account the Earth's cross-sectional surface area and the contribution from the albedo, this corresponds approximately to a peak surface forcing of $0.6 \mathrm{~W} \mathrm{~m}^{-2}$. In addition, ten simulations have been performed using realistic forcings over the period AD 1000-2000, i.e. the main natural (solar and volcanic) and anthropogenic forcings (increase in greenhouse gas concentrations and in sulfate aerosol load). The evolution of solar irradiance follows the reconstruction of Lean et al. [1995] extended back in time [Bard et al., 2000]. In contrast with previous studies analyzing shorter time periods [Shindell et al., 2001], the model does not include a representation of the effect of changes in solar irradiance on stratospheric ozone concentration. This could have an impact on the simulated response of the tropospheric circulation to the forcing. The effect of volcanism is derived from Crowley [2000] and is included through changes in solar irradiance. The influence of sulfate aero- 
sols is taken into account through a modification of surface albedo. The 10 simulations differ only in their initial conditions.

[5] In addition to some previously published data sets, water stable isotopes $\left(\delta^{18} \mathrm{O}, \delta \mathrm{D}\right)$ measured at approximately annual resolution along the DSS (Dome Summit South) ice core drilled on Law Dome $\left(66.46^{\circ} \mathrm{S}, 112.48^{\circ} \mathrm{E}, 1390 \mathrm{~m}\right.$ above sea level) have been used for model-data comparison. The measurement technique and analytical precision are described in Delmotte et al. [2000] and Masson-Delmotte et al. [2003], but we provide here a longer time series. The deuterium excess is a second order isotopic parameter $(\mathrm{d}=$ $\left.\delta \mathrm{D}-8 * \delta^{18} \mathrm{O}\right)$ significantly driven by the sea surface temperature at the oceanic moisture source of the precipitation which, for Law Dome, is mainly located in the Indian sector of the Southern Ocean. If no major change occurs in the location of the moisture source, deuterium excess is thus related to change in sea surface temperature there [Delmotte et al., 2000; Masson-Delmotte et al., 2003].

\section{Idealized Forcing}

[6] In the experiment with the idealized forcing, the Northern Hemisphere surface temperature is nearly in phase with the forcing. The maximum correlation between this low frequency forcing and surface temperature averaged over the hemisphere is found when the latter is lagging by 25 years. In contrast, the response of the surface temperature in the Southern Ocean is significantly delayed, with the maximum correlation found for a lag of 145 years there.

[7] Various oceanic processes might be responsible for this inter-hemispheric phase lag. First, the thermal inertia of the ocean can be invoked, but it cannot explain such a long lag. This is demonstrated using a one-dimensional (1-D) ocean model, driven by the same variations in external forcing as ECBILT-CLIO. With this 1-D model, it is not possible to simulate a delay longer than 30 years. Furthermore, the upward oceanic heat flux at surface southward of $60^{\circ} \mathrm{S}$ becomes positive around year 250 (i.e., at the maximum of the forcing) and reaches $+2 \mathrm{~W} \mathrm{~m}^{-2}$ in zonal mean 150 years after the forcing maximum. At this time, the ocean accumulates heat (i.e., negative upward heat flux at surface) in nearly all the other regions because of the positive forcing. This confirms that, in addition to the local heat storage, three-dimensional effects must be responsible for the long delay.

[8] A plausible mechanism would be an anti-phase relationship between the North Atlantic and the Southern Ocean due to a weakening of the oceanic thermohaline circulation during warm periods in the Northern Hemisphere [Stocker, 1998; Broecker, 2001]. In our simulations, however, the low frequency variations of the deep-ocean-circulation intensity, as measured by the maximum of the export of North Atlantic Deep Water out of the Atlantic at $30^{\circ} \mathrm{S}$, reach at most $1 \mathrm{~Sv}$ and they are only weakly correlated with the forcing $(0.20)$.

[9] We therefore propose another mechanism related to the upwelling of relatively warm deep water in the Southern Ocean. The maximum correlation between deep temperature in the Southern Ocean at $50^{\circ} \mathrm{S}$ and the forcing is found for a lag of 245 years, i.e., 100 years later than at surface. This long delay appears to be due to the transport of warm anomalies created in the North Atlantic when forcing at

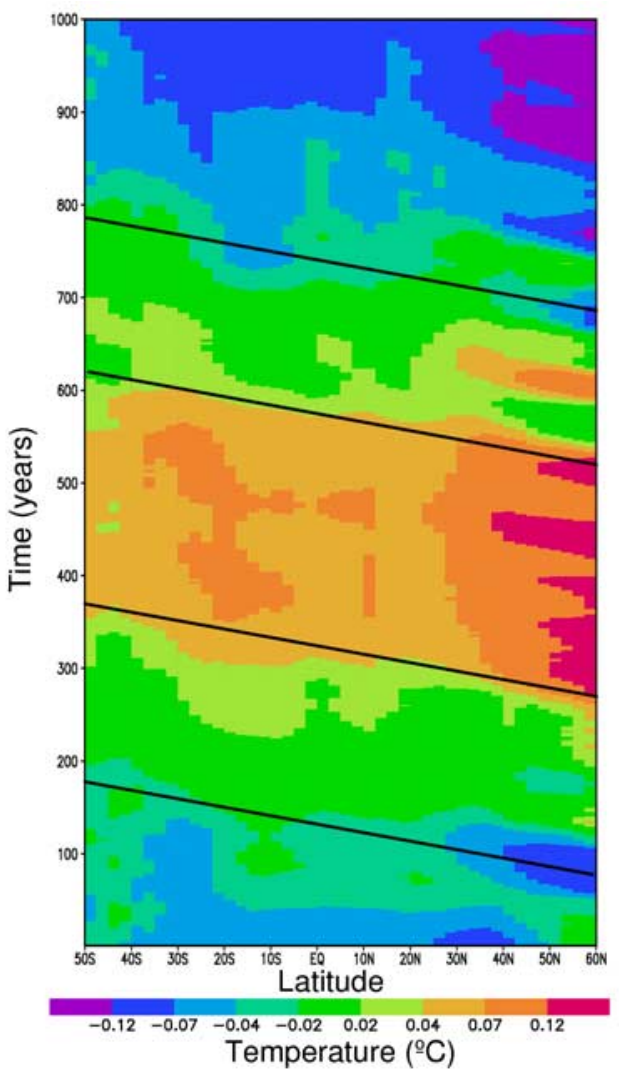

Figure 1. The zonal mean of the temperature anomaly in the ocean between 1000 and $3500 \mathrm{~m}$ depth in the Atlantic is shown as a function of time in a simulation driven by a sinusoidal forcing from variations in solar irradiance with a period of 1000 years and an amplitude of $3 \mathrm{~W} \mathrm{~m}^{-2}$. The maximum of the forcing is reached at year 250, while the minimum occurs at year 750 . The black lines underline the propagation of the anomalies and correspond to a propagation from the north Atlantic to the Southern Ocean in 100 years.

surface is strong there. Because of the large heat capacity of the ocean, the maximum temperature in the deep North Atlantic at $45^{\circ} \mathrm{N}$ is found about 150 years after the maximum in the forcing.

[10] The warm anomalies propagate towards the Southern Ocean in 90 to 100 years (Figure 1). This time scale is consistent with previous estimates of the time needed for a deep anomaly originating from the North Atlantic to influence the Southern Ocean [e.g., England and Holloway, 1998]. Nevertheless, because of its coarse resolution, the model is not able to simulate well the fast currents and this estimate of the advective time-scale must be taken with caution. In contrast to the changes in the intensity of the thermohaline circulation, this southward transport of anomalies appears robust during the whole simulation.

[11] The warm anomalies upwell towards the surface mainly southward of $60^{\circ} \mathrm{S}$ in the model. The temperature changes at the ocean surface in this region have a magnitude of $0.2^{\circ} \mathrm{C}$, about twice of the magnitude at depth. As a consequence, the deep anomalies are large enough to play a role in the delayed temperature evolution at surface, but local feedback such as the classical temperature-albedo feedback 

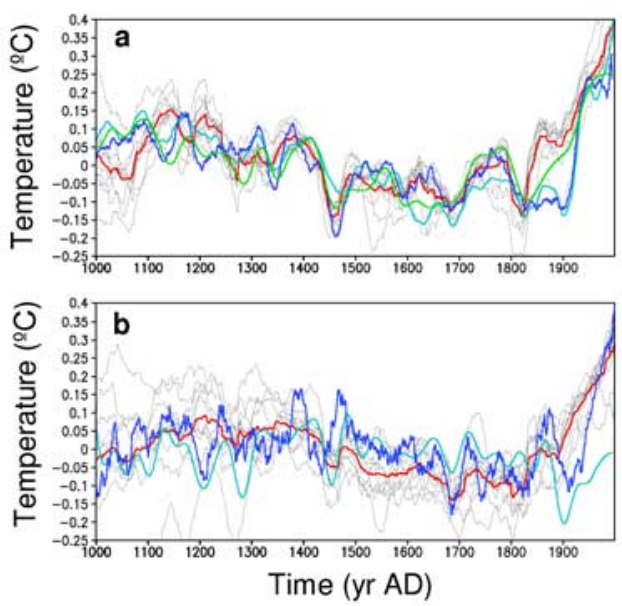

Figure 2. (a) Anomaly of annual mean surface temperature averaged over the Northern Hemisphere in 10 simulations (grey) and their mean (red). The temperature reconstructions are in dark blue [Mann et al., 1999], light blue [Crowley and Lowery, 2000] and green [Mann and Jones, 2003]. (b) Same as figure a for the Southern Hemisphere. The reconstructions are in dark blue [Jones et al., 1998] and light blue [Mann and Jones, 2003].

are clearly needed to explain the magnitude of the changes. It must be stressed that the upward heat flux in the ocean is increasing until year 500, because of the long delay of the deep temperatures. Nevertheless, the highest temperatures are found at the surface around year 400 because after this date the upwelling of warmer waters is not able to compensate anymore for the decrease in surface forcing.

\section{Forcing Over the Last Millennium}

[12] The simulations performed using a realistic forcing reproduce reasonably well the reconstructed temperature evolution in both hemispheres (Figure 2). In the Northern Hemisphere, the model displays relatively warm conditions during the 12th and 13th Centuries AD. This is followed by a gradual cooling from the end of the 13th to the beginning of the 19th Century and finally, a warming during the last 150 years of the experiment. In the Southern Hemisphere, the amplitude of the variation appears smaller at low frequency, although the 13th to 15 th Centuries are slightly warmer than the 18th and 19th Centuries. Note that the reconstruction of Mann and Jones [2003] does not display a large warming during the 20th Century in contrast with observations based on thermometers that show a warming during this period of about $0.5^{\circ} \mathrm{C}$, in agreement with model results.

[13] At the regional scale, the role of the internal variations is generally much larger than at the hemispheric scale. For instance, the amplitude of the modelled climate fluctuations at mid-latitudes in the Southern Hemisphere has the same order of magnitude as the dispersion between the various experiments. Any warm period detected in those areas [e.g., Cook et al., 2002] is thus in the model more related to local/regional modes of variability than to a largescale response to the forcing. Nevertheless, one must be careful here and should not extrapolate this conclusion for any region of the world. Further studies are needed to quantitatively assess the impact of external forcing for the different regions and some processes not well represented in ECBILT-CLIO might play an important role in this response.

[14] In the Southern Ocean area, the centennial-scale fluctuations are systematically amplified in our simulations. The surface temperature averaged over the 10 simulations appears clearly higher during the 13th, 14th and 15th Centuries than during any period before the 20th Century (Figure 3). Between AD 1300 and 1450, the average surface
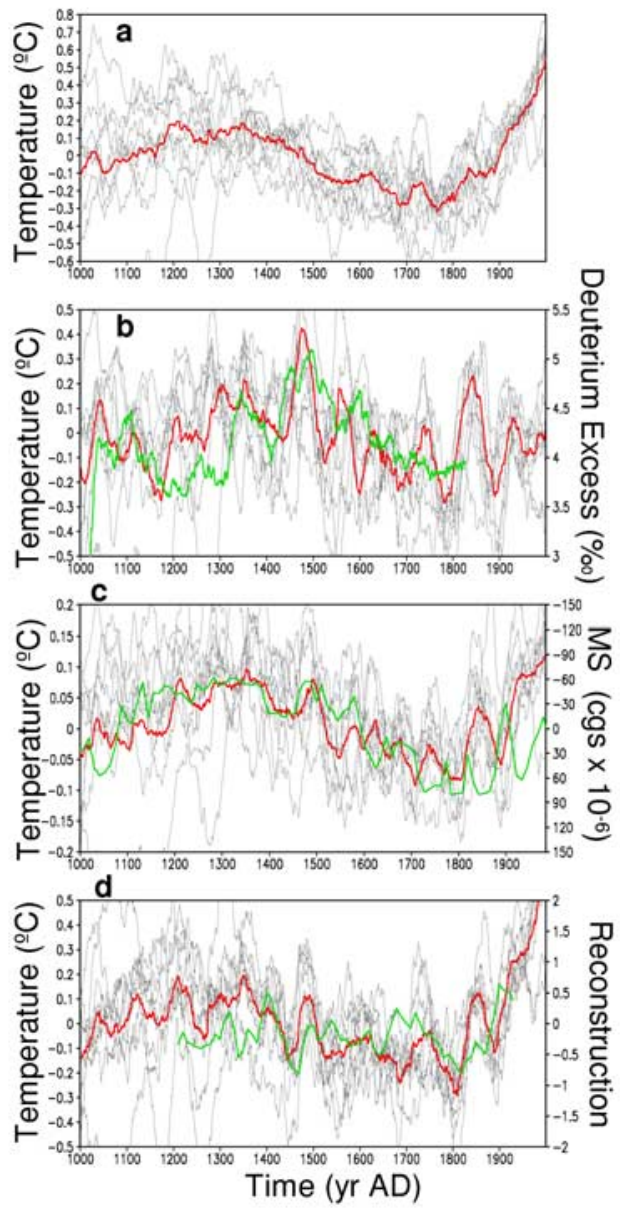

Figure 3. (a) Annual mean temperature averaged over the latitudes $55^{\circ}-75^{\circ} \mathrm{S}$ in an ensemble of 10 simulations (grey) and their mean (red). (b) Same as (a) for the annual mean surface temperature averaged over the region $45^{\circ}-60^{\circ} \mathrm{S}$, $90^{\circ}-130^{\circ} \mathrm{E}$ and the deuterium excess measured in the Law Dome ice core, $67^{\circ} \mathrm{S}-113^{\circ} \mathrm{E}$ (green curve, left vertical axes). (c) Same as (a) for the annual mean ocean temperature between 0 and $100 \mathrm{~m}$ averaged over the region $60^{\circ}-63^{\circ} \mathrm{S}, 55^{\circ}-60^{\circ} \mathrm{W}$ and the anomaly of magnetic susceptibility (MS) measured in the Bransfield Basin, $62^{\circ} \mathrm{S}-55^{\circ} \mathrm{W}$ (green curve, left vertical axes) (in $10^{6} \mathrm{cgs}$ ). (d) Annual mean surface temperature averaged over the region $68^{\circ}-90^{\circ} \mathrm{S}, 70^{\circ}-190^{\circ} \mathrm{E}$ and the average for $\mathrm{AD} 1200$ to 1900 of deuterium measured at Dome $\mathrm{C}\left(75^{\circ} \mathrm{S}, 123^{\circ} \mathrm{E}\right)$, Law Dome $\left(67^{\circ} \mathrm{S}, 113^{\circ} \mathrm{E}\right)$, South Pole and Talos Dome $\left(72^{\circ} \mathrm{S}, 159^{\circ} \mathrm{E}\right)$ and $\delta^{18} \mathrm{O}$ measured at Taylor Dome $\left(77^{\circ} \mathrm{S}\right.$, $\left.158^{\circ} \mathrm{E}\right)$. Before making this average, we have subtracted for each isotope time series its mean and divided it by its standard deviation. This compilation of ice core measurements reflects the temperature evolution over Antarctica. 
temperature of the Southern Ocean is higher than the mean over the period $1000-1750$ by at least $0.17^{\circ} \mathrm{C}$ in all simulations. In a very long control experiment performed with ECBILT-CLIO using forcings corresponding to the year AD 1750, the probability of such a prolonged warm period due to internal climate variability is once every 7500 years. It is thus unlikely that this warm period occurred by chance in all the 10 experiments at the same time.

[15] The warm conditions in the Southern Hemisphere appear delayed compared to the Northern Hemisphere whose surface temperature evolution is nearly in phase with the forcing. A detailed analysis of the model results reveals that the transport of warm anomalies, created in the North Atlantic when conditions are warm there at surface, towards the Southern Ocean is responsible for the delay in our experiments. This mechanism is identical to the one described for the simulation using idealized forcing.

[16] The modeled signal in the Southern Ocean region during the last millennium can be compared with the few available proxies at high southern latitudes. First, the deuterium excess measured at Law Dome offers a unique opportunity to gain insights into interannual changes of sea-surface temperature [Delmotte et al., 2000; MassonDelmotte et al., 2003]. This new paleoclimatic archive exhibits high values (corresponding to warm conditions) during the 14th and 15th Centuries, followed by a decreasing trend until AD 1850. The simulated Southern Ocean surface temperatures coincide well with those measurements.

[17] Although the precise dating of marine records is difficult to obtain due to large uncertainties [Khim et al., 2002], they provide an independent source of information in the Southern Ocean, compared to model results and deuterium excess measurement. Analyzing a marine core close to the Antarctic Peninsula, Khim et al. [2002] showed higher magnetic susceptibility during the period AD 1250-1450. They show that this high signal reflects warmer ocean surface conditions during this period, in a good agreement with simulated ocean temperatures in this area.

[18] Over Antarctica, the proxies of surface temperature appear strongly influenced by the natural variability noticed at each site. Nevertheless, on the basis of a new compilation of various temperature proxies obtained over Antarctica [Delmotte, 2000; Steig et al., 2000; Stenni et al., 2002], it is possible to show that the temperature recorded at large scale exhibits generally cold values after the mid 15th Century preceded by higher temperatures, but the signal is less clear than in the two previous records.

\section{Conclusions}

[19] Although more data about the temperature evolution in the Southern Hemisphere are clearly needed, available paleoclimatic proxies give evidence of warm Southern Ocean conditions during the 14th and 15th Centuries, consistent with model ensemble simulations. The signal at mid- and low latitudes as well as averaged over the entire Southern Hemisphere appears less clear. In contrast, the Northern Hemisphere was already cooling at all latitudes during this period. The mechanism proposed here on the basis of model results provide a reasonable hypothesis to explain phase lags of about 150 years between climate changes in the Northern Hemisphere and in the Southern Ocean for past climate changes. Furthermore, our results could help understanding of the future climate evolution. The mechanism evidenced here suggests that the present-day Southern Ocean has not yet completely responded to the increase in the atmospheric greenhouse-gas concentrations observed during the past century. Our results would then imply a large warming in the Southern Ocean when the warm deep water formed during the 20th Century have reached the Southern Ocean surface. In this framework, the oceanic warming observed during the last 50 years [Levitus et al., 2000] would imply a strong climatic delayed-action effect.

[20] Acknowledgments. C. Bertrand and E. Driesschaert help in the coding of the forcing due to aerosols. This study is supported by the Federal Science Policy Office (Belgium). T. F. and H.G. are research associate with the Belgian National Fund for Scientific Research. BKK is partly supported by the research grant PP04106.

\section{References}

Bard, E., et al. (2000), Solar irradiance during the last 1200 years based on cosmogenic nuclides, Tellus, 52B, 985-992.

Bradley, R. (2000), 1000 years of climate change, Science, 288, $1353-$ 1354.

Broecker, W. S. (2001), Was the Medieval Warm Period global?, Science, 291, 1497-1499.

Cook, E. R., J. G. Palmer, and R. D. D'Arrigo (2002), Evidence for a 'Medieval Warm Period' in a 1,100 year tree-ring reconstruction of past austral summer temperatures in New Zealand, Geophys. Res. Lett., 29(14), 1667, doi:10.1029/2001GL014580.

Crowley, T. J. (2000), Causes of climate change over the past 1000 years, Science, 289, 270-277.

Crowley, T. J., and T. S. Lowery (2000), How warm was the Medieval Warm Period?, Ambio, 29, 51-54.

Delmotte, M., et al. (2000), A seasonal deuterium excess signal at Law Dome, coastal eastern Antarctica: a southern ocean signature, J. Geophys. Res., 105(D6), 7187-7197.

England, M. H., and G. Holloway (1998), Simulation of CFC content and water mass age in the deep North Atlantic, J. Geophys. Res., 103(C8), $15,885-15,901$

Goosse, H., and T. Fichefet (1999), Importance of ice-ocean interactions for the global ocean circulation: a model study, J. Geophys. Res., 104(C10), $23,337-23,355$

Jones, P. D., et al. (1998), High-resolution palaeoclimatic records for the last millennium: interpretation, integration and comparison with General Circulation Model control-run temperatures, The Holocene, 8, 455-47.

Khim, B. K., et al. (2002), Unstable climate oscillations during the late Holocene in the Eastern Bransfield Basin, Antarctic Peninsula, Quat. Res., 57, 234-245.

Lean, J., J. Beer, and R. Bradley (1995), Reconstruction of solar irradiance since 1610: Implications for climate change, Geophys. Res. Lett., 22(23), $1591-1594$

Levitus, S., et al. (2000), Warming of the World Ocean, Science, 287, $2225-2228$.

Mann, M. E., R. S. Bradley, and M. K. Hughes (1999), Northern Hemisphere temperatures during the past millennium: inferences, uncertainties, and limitations, Geophys. Res. Lett., 26(6), 759-762.

Mann, M. E., and P. D. Jones (2003), Global surface temperatures over the past two millennia, Geophys. Res. Lett., 30(15), 1820, doi:10.1029/ 2003 GL017814.

Masson-Delmotte, V., et al. (2003), Recent southern Indian Ocean climate variability inferred from a Law Dome ice core: new insights for the interpretation of coastal Antarctic isotopic records, Clim. Dyn., 21, $153-166$.

Opsteegh, J. D., et al. (1998), ECBILT: A dynamic alternative to mixed boundary conditions in ocean models, Tellus, 50A, 348-367.

Shindell, D. T., et al. (2001), Solar forcing of regional climate change during the Maunder Minimum, Science, 294, 2149-2152.

Steig, E. J., et al. (2000), Wisconsinan and Holocene climate history from an ice core at Taylor Dome, western Ross Embayment, Antarctica, Geografiska Annaler, 82A, 213-235.

Stenni, B., et al. (2002), Eight centuries of volcanic signal and climate change at Talos Dome (East Antarctica), J. Geophys. Res., 107(D9), 4076, doi:10.1029/2000JD000317. 
Stocker, T. F. (1998), The seesaw effect, Science, 282, 61-62.

M. Delmotte and V. Masson-Delmotte, Laboratoire des Sciences du Climat et de l'Environnement, IPSL, UMR CEA-CNRS, L'Orme des Merisiers, Gif-sur-Yvette, France.

T. Fichefet and H. Goosse, Institut d'Astronomie et de Géophysique G. Lemaître, Université Catholique de Louvain, Louvain-la-Neuve, Belgium. (hgs@astr.ucl.ac.be)
B. K. Khim, Dept. of Marine Science, Pusan National University, Pusan, Korea.

V. Morgan and T. van Ommen, Department of the Environment and Heritage, Australian Antarctic Division, and Antarctic Climate and Ecosystems CRC, Hobart, Tasmania, Australia.

H. Renssen, Faculty of Earth and Life Sciences, Vrije Universiteit Amsterdam, The Netherlands.

B. Stenni, University of Trieste, Dipartimento di Scienze Geologiche, Ambientali e Marine, Trieste, Italy. 